\title{
Analysis of Organic Lettuce Supply Chain Institutions
}

\author{
Chusnatul Ulaela Sajali ${ }^{*}$, Budi Setiawan ${ }^{2}$, Djoko Koestiono \\ ${ }^{1}$ Postgraduate Program in Agricultural Economics, Faculty of Agriculture, Brawijaya University \\ ${ }^{2}$ Socio-Economics Department, Faculty of Agriculture, University of Brawijaya, Jl. Veteran Malang \\ 65145, Jawa Timur, Indonesia
}

Received: 13 July 2017; Revised: 8 January 2018; Accepted: 5 March 2018

\begin{abstract}
Supply chains are formed due to the need of farmers, wholesalers, retailers, supermarkets, and consumers. With a large number of agents in the organic lettuce production starting from the farmers up to supermarkets, it turns out that supply chain management has not proceeded well. Each agent has still nogood cooperation and relationship because they only work and focus on their own goals. Information desired by consumers only reaches the retailers, not up to the farmers as suppliers. This research was aimed to identify the structure of organic lettuce supply chain flow, to analyze the performance of organic lettuce supply chain management, and to formulate alternative solutions for the management performance improvement in the organic lettuce supply chain. The results showed that the agents of the supply chain in the flow of information have not flowed perfectly and completely. Improved and better supply chain management performance is highly required at wholesalers and retailers.
\end{abstract}

Keywords: supply chain; organic lettuce; institution; analysis of SCOR

How to cite:

Sajali, C. U., Setiawan, B., \& Koestiono, D. (2018). Analysis of Organic Lettuce Supply Chain Institutions. HABITAT, 29(1), 1-10. https://doi.org/10.21776/ub.habitat.2018.029.1.1

\section{Introduction}

In general, institutions of horticultural supply chains still have some constraints including the product-marketing channel that is still too long, the market structure form that leads to oligopsonistic, and the distribution of remuneration to the marketing function that is still uneven (Saptana, 2006). Therefore, the institutions still need improvements as stated by Anantayu (2011) on the integrated institutional system. The development of an integrated institutional system will make the supply chain more efficient by reducing the price margin. This also will make the price of horticultural products, particularly vegetables, become cheaper and competitive. Although there are still some constraints emerging, the role of farmer institutions can determine the success of agricultural development and contribute to the speed of obtaining agricultural information and socio-economic development and the speed of

*Corresponding author

E-mail: chusnatululaela@gmail.com

Telp: +62 857-3557-8878 gaining capitals, infrastructure and market conditions. Besides, farmer institutions provide adoption of agricultural innovations (Anantanyu, 2011). Hidayanto et al. (2009) also stated that the development of farmer institutions is highly important since 1) it can solve many agricultural problems; 2) it provides continuity in the effort of disseminating technology or technical knowledge to the farmers; 3 ) it prepares the farmers to compete in the more open economic structure; and 4) it builds farmer cooperation that can encourage the use of farmers' resources to be more efficient.

Uphoff (1986) revealed that farmer institutions are the institutions formed by farmers located in a locality area which are in the form of membership organization or cooperation, i.e. farmers who are members of cooperation groups. Therefore, farmer institutions will need and relate each other. Furthermore, Dwi Retno (2012) argued that farmer institutions are managed in more modern ways, such as farmer groups, water user groups, business credit groups, village cooperatives, marketing groups, breeder groups and so on. 
According to Marimin (2019), vegetable supply chain management has special characteristics as follows: 2) vegetables are easily damaged/ rotten, 2) in terms of cultivation activities, vegetables tend to depend on climatic or seasonal conditions, 3) vegetable yields have varying sizes and shapes, 4) vegetables are difficult to transport and manage because they have various shapes, and 5) vegetable supply chain management has various forms of partnership starting from informal to formal.

In supply chain activities, the institutions involved will relate to each other. Supply chain needs will also associate with one another. If one of the institutions undergoes a change, it will affect other institutions. In addition, if there is a fulfillment of one need, it will also affect other needs. The inter-agency relationship should be managed as a whole (Marimin, 2010).

A supply chain is initially formed due to the needs of consumers, such as the case examples in the book of Chopra and Meindl (2001) in which a detergent supply chain is formed by the need of consumers to buy detergent. As the example, consumers visit WalMart as a retail store and Wal-Mart itself obtains detergent supplies from a warehouse or distributor transported using a truck. The warehouse or distributor gets the detergent supplies from $P \& G$ big factory. $P \& G$ obtains the raw materials for detergent manufacture from many suppliers in which the suppliers are also supplied by other suppliers. As another example, packaging plastics are obtained from Tenneco, and Tenneco itself obtains the raw materials from other suppliers. However, over time, the supply chain not only becomes the need of consumers. Indrajit (2005) explained that a supply chain is a system used by organizations to deliver goods and services to customers. Moreover, Pujawan (2005) stated that a supply chain is a network of manufacturers who work together to produce and deliver products to the end users or consumers. It consists of suppliers, manufacturers/ factory, distributors, retailers, and outlets as well as other supporting companies such as logistics service companies. This chain has the same primary goal of providing the distribution or procurement of production goods and services to the end users/ consumers.

In this research, the commodity studied was organic lettuce - lettuce crops cultivated without the use of pesticides and chemical fertilizers. As it is known, nowadays, the consumption of organic vegetables is increasingly in demand by consumers. However, based on the field condition, farmers are still not able to face directly the markets. Therefore, farmers still need cooperation with other institutions associated with the required fields. Institutions involved are farmers, wholesalers, retailers, and supermarkets.

By aligning the vision and mission as well as the coordination of good cooperation between institutions, the purpose of a good system of supply chain management can be achieved. Thus, with this background, the researchers intended to conduct a research about the existing institutions of the organic lettuce supply chain.

\section{Research Objectives}

The objectives to be achieved in this research are as follows:

a. To analyze the supply chain institutions of organic lettuce

b. To analyze the organic lettuce supply chain

\section{Research Method}

\subsection{Determination of Location and Time of Research}

Determination of the research location was done purposively, which involved organic lettuce farmers in Sumberdadi Village, Sumbergempol District, Tulungagung Regency. This research was conducted starting from August to October 2016.

\subsection{Data Collection}

The types and sources of data used in this research consisted of primary and secondary data. The data were collected purposively. The first objective of this research was analyzed by indepth interviews with 5-10 members of organic lettuce supply chain institutions. The institutional members consisted of 5 farmers (the Chairman, Vice, Secretary, and 2 farmer group members), 1 wholesaler, 1 retailer, and 3 supermarkets. The interviewer performed this interview technique by interviewing each of the selected interviewees face-to-face.

In analyzing the second objective, a questionnaire technique was applied. A questionnaire is a data collection technique done by giving a set of questions or statements to other people (selected as respondents) to be answered. In this research, the questionnaires were given to 
26 farmers, 2 wholesalers, 2 retailers and 4 supermarkets.

\subsection{Data Analysis}

\subsubsection{Institutions of Organic Lettuce Supply Chain}

A qualitative descriptive method was used to analyze the organic lettuce supply chain institutions starting from farmers to modern retail companies/ supermarkets. Some of the things explained in detail are the activities and characteristics of each agent in the organic lettuce supply chain starting from farmers to supermarkets.

\subsubsection{Organic Lettuce Supply Chain}

SCOR (Supply Chain Operation Reference) approach model was applied to solve the second problem or objective, that was to analyze the performance of organic lettuce supply chain management. This approach model consists of three detailed levels (hierarchy). The first level (Level 1) is the highest level that provides a general definition of five basic processes, namely planning, procurement, production, distribution and return. The second level (Level 2) is the translation or explanation of each process mentioned in Level 1 into several types and categories of processes, namely reliability, responsiveness, flexibility, cost, and assets. The process category determination is useful for defining the occurring supply chain processes. The third level (Level 3) is a sequence of processes occurring in each process of Level 2, namely perfect order fulfilment, delivery performance, lead-time, supply chain flexibility, supply chain adjustment, product cost, and cashto-cash cycle. The five basic processes in SCOR approach model are planning (plan), procurement (source), production (make), distribution (deliver) and return. Each performance indicator is described in the table as follows:

Each indicator of supply chain performance in the organic lettuce supply chain provides achievable results that can be categorized as follows:
a. Poor : performance indicator value $<40$
b. Marginal :performance indicator value between $40-50$
c. Average :performance indicator value between $51-70$
d. Good :performance indicator value between $71-90$
e. Excellent :performance indicator value $>90$

\section{Results and Discussion}

\subsection{Institutions of Organic Lettuce Supply Chain}

Members of the supply chain structure of organic lettuce in Sumberdadi Village generally consist of farmers, wholesalers, and modern retail companies/ supermarkets.

A study conducted by Rahayu and Kartika (2015) suggested that the problems occuring in the potato supply chain institutions in Banjarnegara Regency were as follows: 1) the research results were not implemented sustainably; 2) the partnership with the companies did not proceed well; 3 ) many traders did not pay accordingly to the agreement; 4) traders found it difficult to select farmers whose products meet export standards; 5) the access to information was limited; 6) the access to the means of potato product marketing was limited; 7) the number of competent farmers was very small; 8) the number of available certified potato seeds did not meet the needs; 9) the number of the use of pesticides exceeded the limit; and 10) directing farmers to do cultivation with Good Agriculture Practice (GAP) was difficult.

Moreover, the results of a research conducted by Mustaniroh et al. (2015) using Interpretive Structural Modelling (ISM) showed that the element of needs had two levels, with the key sub-elements covering the good apple production, qualified raw materials, and availability of capital for production, qualified human resources, and appropriate product marketing strategies.

Meanwhile, the element of constraints had six levels in which the key sub-elements were that the capital source was difficult to obtain and the human resources were less skilled in the independent sector. On the other side, the element of involved institutions had four levels, with the key sub-element that was the government. The sub-element was in the independent sector, affecting farmers and farmer groups in the Linkage sector.

According to Padmaningrum and Wibowo (2010), the local institutional conditions of agriculture in the development of carrot agribusiness are as follows: 1) Village Unit Cooperatives $(K U D)$ only focus on the provision of production facilities, especially subsidized fertilizers; 2) Rural Bank (BPR) and District Credit Agency are not optimally utilized by farmers, not only because most farmers use their 
own capital in carrot farming, but also due to the long procedures of credit taking for capital; 3) Markets at village, district or regency levels have a role in carrot agribusiness which is as the place for farmers selling their carrot crops; 4) the institutional counseling has a role in the development of carrot agribusiness through extension programs. The constraints faced by extension workers in the development of carrot agribusiness include: 1) the difficulty of changing the farmers' behaviours to farm organically because farmers tend not to take risks by trial and error; 2) the high difficulty of changing or encouraging farmers to switch their seeds to new varieties; 3) the fluctuation in carrot prices causing farmers to lose and are reluctant to develop their farms; 4) the difficulty of marketing instant carrot processed products.

The chain of organic lettuce chain can be seen in Figure 1 below:

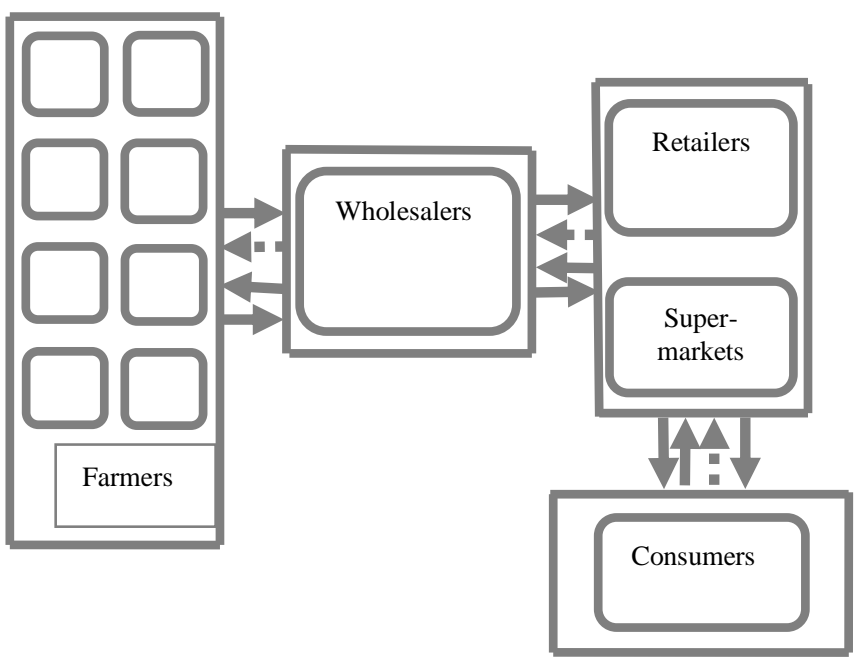

Figure 1. Organic Lettuce Supply Chain Flow

Description :

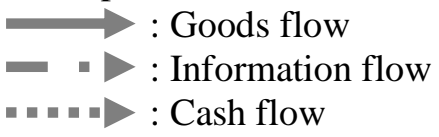

Based on Figure 1, the flow of goods in the supply chain of organic lettuce started from the farmers performing the activities of organic lettuce cultivation. The flow of goods then continued from the farmers to wholesalers in which the goods had already been in the form of organic lettuce commodities. The wholesalers then distributed the organic lettuce to supermarkets and traditional markets. Prior to being distributed, the organic lettuce had gone through the process of sorting and grading, categorized into two types (grades). The difference is tailored to the demand of supermarkets and traditional markets. Supermarkets require organic lettuce packaged using a thicker plastic and use a label/brand on the packaging. On another side, traditional markets require organic lettuce packaged using a thin plastic only and without using a label/brand. The purpose of the use of thick plastic packaging and the label/ brand for the organic lettuce products in supermarkets is to make sure that consumers receive the products with a good quality. Plastic packaging that is not easily damaged will keep the freshness of organic lettuce.

Furthermore, the labelling/ branding aims to make consumers more convinced that the products they receive or buy are organic. Once in the supermarkets, the product packaging would be added with the price tag along with the organic lettuce product weight information. This is intended to make consumers more quickly to get information on the product prices in accordance with the weight of the organic lettuce products bought so that the weight or amount of organic lettuce products to be bought is in line with the consumers' needs. In general, price labelling is adjusted to the concept of supermarkets, which is without any bargaining transaction. The flow structure development of organic lettuce supply chains can be done on the scheme as in the above questions.

It was known that supermarkets received organic lettuce with grade A from the wholesaler 1. Meanwhile, the wholesaler 2 delivered organic lettuce with grade B to the retailers in traditional markets.

The things mentioned above cannot be separated from the rights and obligations of all agents of the organic lettuce supply chain. Here is the description of the rights and obligations of each agent of the organic lettuce supply chain:

Table 1. Main Duties and Functions of Organic Lettuce Supply Chain Agents

\begin{tabular}{|c|c|c|}
\hline Agent & Right & Obligation \\
\hline a. Farmers & $\begin{array}{l}\text { 1. Obtaining } \\
\text { organic } \\
\text { lettuce } \\
\text { prices } \\
\text { according } \\
\text { to the } \\
\text { quality }\end{array}$ & $\begin{array}{l}\text { 1. Setting a } \\
\text { planting } \\
\text { schedule and } \\
\text { production } \\
\text { schedule to be } \\
\text { agreed by the } \\
\text { wholesalers. }\end{array}$ \\
\hline
\end{tabular}




\begin{tabular}{|c|c|c|}
\hline & $\begin{array}{l}\text { provided to } \\
\text { the } \\
\text { wholesalers } \\
\text { 2. Obtaining } \\
\text { capital } \\
\text { loans from } \\
\text { the } \\
\text { wholesalers }\end{array}$ & $\begin{array}{l}\text { 2. Implementing } \\
\text { organic lettuce } \\
\text { cultivation } \\
\text { activities } \\
\text { according to } \\
\text { the agreed } \\
\text { standards } \\
\text { 3. Providing } \\
\text { organic lettuce } \\
\text { to the } \\
\text { wholesalers } \\
\text { according to } \\
\text { the production } \\
\text { schedule } \\
\text { 4. Selling all the } \\
\text { organic lettuce } \\
\text { products to } \\
\text { the } \\
\text { wholesalers }\end{array}$ \\
\hline $\begin{array}{l}\text { b. Wholesal } \\
\text { ers }\end{array}$ & $\begin{array}{l}\text { 1. Receiving } \\
\text { organic } \\
\text { lettuce } \\
\text { payments } \\
\text { that have } \\
\text { been } \\
\text { earned by } \\
\text { the modern } \\
\text { retail } \\
\text { companies/ } \\
\text { supermark } \\
\text { ets }\end{array}$ & $\begin{array}{l}\text { 1. Performing } \\
\text { marketing } \\
\text { activities of } \\
\text { farmers' crops } \\
\text { 2. Buying all } \\
\text { organic lettuce } \\
\text { yields } \\
\text { according to } \\
\text { the agreed } \\
\text { harvest } \\
\text { schedule } \\
\text { 3. Making } \\
\text { payments to } \\
\text { organic lettuce } \\
\text { farmers } \\
\text { according to } \\
\text { the agreed } \\
\text { price and time } \\
\text { 3. Packaging } \\
\text { organic lettuce } \\
\text { according to } \\
\text { the deal with } \\
\text { the modern } \\
\text { retail } \\
\text { companies/ } \\
\text { supermarkets }\end{array}$ \\
\hline c. Retailer & $\begin{array}{l}\text { 1. Obtaining } \\
\text { organic } \\
\text { lettuce } \\
\text { according } \\
\text { to the } \\
\text { agreed } \\
\text { quality of } \\
\text { grade B }\end{array}$ & $\begin{array}{l}\text { 1. Making } \\
\text { payments to } \\
\text { the } \\
\text { wholesalers } \\
\text { according to } \\
\text { the agreed } \\
\text { price and time }\end{array}$ \\
\hline
\end{tabular}

\begin{tabular}{|c|c|c|}
\hline $\begin{array}{l}\text { d.Modern } \\
\text { Retail } \\
\text { Compani } \\
\text { es/Super } \\
\text { markets }\end{array}$ & $\begin{array}{l}\text { 1. Obtaining } \\
\text { organic } \\
\text { lettuce } \\
\text { according } \\
\text { to the } \\
\text { standards } \\
\text { for sale in } \\
\text { modern } \\
\text { retail } \\
\text { companies }\end{array}$ & $\begin{array}{l}\text { 1. Making } \\
\text { payments to } \\
\text { the } \\
\text { wholesalers } \\
\text { according to } \\
\text { the agreed } \\
\text { price and time }\end{array}$ \\
\hline
\end{tabular}

In fulfilling the above obligations, each agent of the supply chain encountered several constraints as follows:

a. Farmers

The farmers experienced difficulties when doing organic lettuce cultivation activities. The farmers were constrained by the erratic weather and climate, such as the increased air temperature (hot weather) in the morning, which then decreased in the daylight. This affected the organic lettuce cultivation productivity and activities. Besides, snails easily attacked organic lettuce plants. Due to the cultivation of organic lettuce, rather than using chemical pesticides, the farmers preferred to implement manual techniques or environmentally friendly materials. Indeed, the farmers were still poorly informed and knowledgeable about the use of organic pesticides.

b. Wholesalers

The wholesaler 1 encountered many requirements and rules when entering supermarkets such as the organic lettuce packaging that should use a thick plastic and a qualified label. In addition, the performances of the wholesalers were influenced by the postharvest and delivery costs.

c. Retailers

The retailers did not meet the consumers' expectations. Many consumers received organic lettuce with a damaged packaging or withered lettuce condition. This was because the retailers just put the organic lettuce on the shelves without equipped with a cooler. In addition, the transportation factor also became one of the causes of the damaged organic lettuce packages.

d. Modern Retail Companies/ Supermarkets

Modern retail companies/ supermarkets were not satisfied with the available amount of organic lettuce. Thus, consumers needed to wait 
several days when they run out of organic lettuce stock in supermarkets.

In overcoming those constraints, here are some recommendations that can be applied:

1) The government together with the related agencies or offices should provide facility and infrastructure assistance in developing organic lettuce cultivation because the majority of the farmers are still lack of equipment in the cultivation of organic lettuce, such as the needs of the hoses provided through cooperation. Moreover, the farmers also expect helps in the form of organic pesticides. This is because most farmers do not know the types of organic pesticides for organic lettuce cultivation. As explained in the previous, farmers tend to overcome pests and diseases attacking organic lettuce plants in simple ways. The government is also expected to provide facilities or means for training wholesalers since wholesalers still can not overcome the transportation problems such as the lack of safe medium provision for transporting organic lettuce.

2) In the development of cultivation and improvement of delivery performance, investment/ capital assistance from financial institutions are also expected to assist farmers and wholesalers. Financial institutions can provide capital to farmers for the provision of facilities and infrastructure in the hydroponically organic lettuce cultivation. Wholesalers can also use capital assistance to provide transportation and medium for delivering organic lettuce to retailers and supermarkets. In addition, if a good cooperation has been well-built, capital assistance can also be given to retailers for providing shelves for the sale of organic lettuce, which is also equipped with a cooler.

3) Technology development can become a solution in enhancing the availability of organic lettuce supplies and in carrying out the packaging activities. The technology development can be a system of planting organic lettuce hydroponically. However, farmers nowadays only have knowledge of planting organic lettuce in polybags. In fact, with the hydroponic system, farmers actually can plant organic lettuce with two planting systems at once. Therefore, the government should cooperate with the relevant agencies or offices in providing knowledge about the hydroponic system of organic lettuce planting to farmers. Organic lettuce is susceptible to pests and diseases if planted in polybag mediums, causing the lack of organic lettuce supplies. Furthermore, organic lettuce plants are also more susceptible to snail pests and easily rotten if there is too much water contained in the soil. Besides, the technology development can also be utilized for manual packaging activities of organic lettuce.

4) So far, the cooperative relationship only occurs between farmers and wholesalers. Farmers actually can offer cooperative relationships with retailers and modern retail companies/ supermarkets. It will have a positive impact because farmers with retailers and modern retail companies/ supermarkets can share information accurately one to another. Both parties will benefit equally if a good cooperative relationship is established. Moreover, there will be an agreement in which the rights and obligations are regulated without harming either party.

5) Training human resources involved in the organic lettuce supply chain is one of the given solutions. This is because farmers have not understood about the development of organic lettuce cultivation and pest eradication using organic pesticides. Training provided by the Office of Agriculture and the Office of Industry and Trade is only related to a way of postharvest handling of organic lettuce. Other than that, farmers rarely get training on the development of organic lettuce cultivation.

\subsection{Organic Lettuce Supply Chain}

\subsubsection{Main Processes in SCOR Model Approach}

a. Plan (Planning)

The planning process undertaken by the farmers covered the planning of production quantities, raw materials, and equipment used for the production of organic lettuce. Differently, at the wholesalers, the planning process was in the 
form of acceptance of orders from the retailers in traditional markets and supermarkets, information sharing with farmers, and time determination for delivering organic lettuce orders.

At the retailers, the planning process was done by ordering organic lettuce to the wholesalers and providing shelves for laying or putting organic lettuce. Meanwhile, at the supermarkets, the planning process was carried out by ordering organic lettuce to the wholesaler 1, providing shelves equipped with a cooler/ refrigerator, preparing price labelling on the organic lettuce packaging, and preparing a special room for organic lettuce reception.

\section{b. Source (Procurement)}

The procurement process by the organic lettuce farmers covered receiving organic lettuce seeds, polybag plastics, manure, and plastic packaging. Meantime, at the wholesalers, the procurement process was in the form of sharing information on the readiness of organic lettuce harvest with the farmers. At the retailers and supermarkets, the procurement process was almost the same, by sharing information with the wholesaler 1 and wholesaler 2 on the organic lettuce delivery schedule.

\section{c. Make (Production)}

The production process done by the farmers was to conduct organic lettuce cultivation activities. Meanwhile, at the wholesalers, this process was done in the form of post-harvest activities such as washing, sorting, grading, labelling, and packaging. The production activities carried out by the retailers were the same with those performed by the supermarkets, by sorting organic lettuce after received. The retailers and supermarkets then selected the organic lettuce that seemed fresh and had neat packaging. The retailers and supermarkets then put the fresh organic lettuce on to prepared shelves.

\section{d. Deliver (Distribution/ Delivery)}

A delivery process is an activity of sending products to the hands of consumers at the right time and place. The activities of product delivery to consumers will involve transportation activities. In the transportation activities, suppliers must manage appropriate distribution networks. In this research, the delivery process undertaken by the farmers was to bring the harvested organic lettuce from the polybag plastics to the harvest baskets. Then, the baskets that had already fulfilled with organic lettuce were brought to the means of transportation to be then delivered to the wholesalers.

Similarly, the wholesalers carried out delivery processes by bringing the organic lettuce to the means of transportation, organizing the transportation activities in the organic lettuce delivery process, and taking care of the organic lettuce during the delivery process to the retailers and supermarkets.

\section{e. Return}

The process of return is the process of returning or accepting the return of organic lettuce due to certain reasons. In this research, the supply chain institutions of organic lettuce that carried out this process were wholesalers. The wholesalers received organic lettuce returned by the retailers and supermarkets, furthermore, the wholesalers managed the administration related to the return of organic lettuce. After that, the wholesalers verified the organic lettuce returned, followed by exchanging the organic lettuce.

\subsubsection{SCOR Card Preparation}

In SCOR approach model, there are three levels that have been described above in detail. The first level (Level 1) is the highest level providing a general definition of five basic supply chain management processes, namely planning (plan), procurement (source), production (make), delivery (deliver), and return. The second level (Level 2) describes the translation or explanation of each process in Level 1 into several types and categories of processes. The determination of process categories is useful for defining the supply chain processes that occur. Meanwhile, the third level outlines the sequence of processes occurring in Level 2.

Another research conducted by Prapti et al. (2015) using Supply Chain Operation Reference (SCOR) approach measured the performance of companies based on the five basic processes: plan, source, make, deliver, and return. The results of the analysis showed that the performance assessment using SCOR approach applied the five perspectives as the core processes. Each perspective used consists of several Key Performance Indicators (KPIs), in which plan consists of 5 KPIs, source consists of $4 \mathrm{KPIs}$, make consists of $7 \mathrm{KPIs}$, deliver consists of 4 KPIs, and return consists of 2 KPIs. 
In this research, SCOR cards provided an overview of the performance calculation and performance indicators of each institution in the organic lettuce supply chain. From the performance assessment, the performance categories of the supply chain institutions of organic lettuce can be known. The performance categories can be considered in the selection of the best alternative solution. The performance attributes used in SCOR cards are reliability, responsiveness, flexibility, cost, and assets. Meanwhile, the performance indicators used in SCOR cards are perfect order fulfilment, delivery performance, lead-time, supply chain flexibility, top supply chain adjustment, product cost, and cash-to-cash cycle.

\section{a. Farmers}

Data used for SCOR card preparation on the farmers were the amount of organic lettuce production in one harvest period. From the SCOR card preparation, it can be found the accuracy of quantity, quality, and delivery of organic lettuce to the wholesalers. Besides, it can also be known the performance assessment and category of the organic lettuce farmers. The farmer performance category can be a consideration in selecting the best alternative solution. The average performance value of all the organic lettuce farmers was 82 , included in the Good category. This category indicates that the average performance value of all the organic lettuce farmers is good. However, the performance of each organic lettuce farmer can still be increased as much as 18 points.

In addition, the farmers had trouble conducting organic lettuce cultivation activities. The farmers were also constrained by the erratic weather and climate, such as the increased air temperature (hot weather) in the morning, which then decreased in the daylight. This affected the organic lettuce cultivation productivity and activities. Besides, snails easily attacked organic lettuce plants. Due to the cultivation of organic lettuce, rather than using chemical pesticides, the farmers preferred to implement manual techniques or environmentally friendly materials. However, the farmers were still poorly informed and knowledgeable about the use of organic pesticides.

\section{b. Wholesalers}

Wholesalers are traders who already have a partnership with farmers. In this research, the wholesalers were in charge of sending organic lettuce to the retailers in traditional markets and supermarkets. The wholesaler 1 would send the grade A-organic lettuce to supermarkets while the wholesaler 2 would send the grade B-organic lettuce to the retailers in traditional markets. Therefore, it can be concluded that there are two types of wholesalers in the organic lettuce delivery. From the SCOR card preparation, it can be known the accuracy of quantity, quality, and delivery of organic lettuce to the retailers and supermarkets. Besides, through the SCOR card preparation, it can also indicate the performance assessment and performance category of the organic lettuce wholesalers. The wholesaler performance category can be a consideration in selecting the best alternative solution.

The results of this research showed that the wholesalers obtained an average performance value of 63, included in the Average category. It means that the average performance of the organic lettuce wholesalers is quite good. However, each wholesaler can still increase the performance value by 37 . The performance value included in the Average category reflects the fact that the wholesalers encountered many requirements and rules when entering supermarkets, one of which is that the organic lettuce packaging should use a thick plastic and a qualified label. In addition, the performances of the wholesalers were influenced by the postharvest and delivery costs.

The wholesaler 2 reached the highest performance value of 70, included in the Average category. On another side, the lowest performance value of 56 was obtained by the wholesaler 1. However, the performance value still includes in the Average category. The lowperformance value was because the farmers got a low delivery performance value and lead-time that was equal to 50 .

c. Retailers

Retailers sell organic lettuce to consumers in traditional markets. They interact directly with consumers such as receiving consumer complaints when the products they buy is not in accordance with what they expected. Based on the SCOR card preparation at the retailers, it can be known the accuracy of quantity, quality, and sales of organic lettuce to consumers. In addition, the results of the SCOR card preparation showed the performance assessment and performance category of the retailers. The retailer performance category can be taken into account in the 
selection of the best alternative solution. According to the analysis results, all the retailers obtained an average performance value of 70 . It means that the performance of all the retailers is included in the Average category. However, each retailer still needs to increase the performance value by 30 . The performance value was in accordance with what occurred in the field where the retailers did not meet the consumers' expectations. Many consumers still received organic lettuce with a damaged packaging or withered lettuce condition. This was because the retailers just put the organic lettuce on the shelves without equipped with a cooler. In addition, the transportation factor also became one of the causes of the damaged organic lettuce packages.

The highest performance value of 79 fell to the retailer 1 . The performance value is included in the Good category. Meanwhile, the lowest performance value was 62 obtained by the retailer 2, also included in the Average category. The low-performance value was because the farmers had a low delivery performance of 50 .

\section{d. Supermarkets}

Supermarkets have the same function as retailers, that is selling products to the consumers. Employees in supermarkets directly interact with consumers such as receiving consumer complaints when the products they buy are not in accordance with what they expected. Based on the SCOR card preparation at the supermarkets, it can be learnt the accuracy of quantity, quality, and sales of organic lettuce to consumers. In addition, the results of the SCOR card preparation showed the performance assessment and performance category of the supermarkets. The supermarket performance category can also be considered in the selection of the best alternative solution. The SCOR card table of the supermarkets suggested that all the supermarkets reached an average performance value of 75 , meaning that the performance of all the supermarkets includes in the Good category. This Good category indicates that all the supermarkets provide a good performance. However, the supermarkets can still improve the performance value by 25 . In addition, consumers in the supermarkets still felt unsatisfied with the supply availability of organic lettuce. As the result, they needed to wait several days when they run out of organic lettuce stock in supermarkets.

\section{Conclusion}

The conclusions that can be drawn from this research are as follows:

The institutions of an organic lettuce supply chain generally involve farmers as organic lettuce suppliers, wholesalers as manufactures, retailers as marketing agents who sell organic lettuce to the end consumers in traditional markets, and supermarkets as marketing agents who sell organic lettuce to the end consumers in modern markets. Activities carried out by the institutions/ agents in the goods flow are as follows: farmers produce organic lettuce and then sell it to wholesalers. The wholesalers then perform sorting, grading, packaging and labelling activities.

After that, the wholesalers continue to sell organic lettuce to retailers in traditional markets and supermarkets. Both retailers and supermarkets sell organic lettuce to the end consumers. The activities carried out by those supply chain agents in the flow of information have not done perfectly and thoroughly as there is no openness of information obtained directly from consumers about the product quality and quantity. The activities of all supply chain agents in the cash flow are starting from consumers who make payments to retailers and supermarkets. Then, both retailers and supermarkets continue the payments or cash flow to the wholesalers, and then the wholesalers do the same thing to the farmers as suppliers.

According to the results of this research, the performance category achievements of the supply chain management of organic lettuce in detail were 82 for organic lettuce farmers, 63 for wholesalers, 70 for retailers, and 75 for supermarkets. It is expected that organic lettuce supply chain agents with performance values categorized into the Average category can improve their performances in organic lettuce supply chain management to be far better.

Inter-agency activities are also expected to support each other in meeting the needs of organic lettuce supply chain. It is aimed to achieve the goals of organic lettuce supply chain.

Furthermore, improvements and enhancements of performance indicators are expected to be made such as the perfect order fulfilment, delivery performance, lead-time, supply chain flexibility, supply chain adjustment, product cost, and cash-to-cash cycle. 


\section{References}

Anantayu, Sapja. 2011. Kelembagaan Petani: Peran dan StrategiPengembangan Kapasitasnya. SEPA: Vol. 7 No.2. Pebruari 2011: 102-109.

Chopra, S and P. Meindl. 2001. Supply Chain Management: Strategy, Planning and Operation. Prentice-Hall, Inc. New Jersey.

Dwi Retno. 2012. Kelembagaan Pertanian. http://dwiretno.lecture.ub.ac.id/files/2012/0 1/Kelembagaan-Pertanian.pptx. Diakses 05 Desember 2017.

Hidayanto, M., Supiandi, S., Yahya, S., \& Amien, L.I. (2009). Analisis Keberlanjutan Perkebunan Kakao Rakyat di Kawasan Perbatasan Pulau Sebatik, Kabupaten Nunukan, Provinsi Kalimantan Timur. Jurnal Agro Ekonomi, 27(2), 213-229.

Indrajit, Richardus Eko, dan Richardus Djokopranoto. 2005. Strategi Manajemen Pembelian dan Supply Chain. Jakarta: PT Grasindo.

Marimin, et.al. 2010. Kebutuhan dan Struktur Kelembagaan Rantai Pasok Buah Manggis (Studi Kasus Rantai Pasok di Kabupaten Bogor).Jurnal Manajemen Bisnis: Vol. 3 No. 1, April-Juli 2010, Hal. 99-115.

Mustaniroh, Siti Asmaul., Effendi, M., Putri I. 2015. Analisis Elemen Kunci dalam Kelembagaan Rantai Pasok Minuman Sari Apel dengan Pendekatan Interpretive Structural Model. ISBN 978-602-7998-926: 68-75.

D. Padmaningrum, Sutarto dan Wibowo, Agung. 2010. Kajian Kelembagaan Agribisnis Wortel Untuk Mendukung Pengembangan Kawasan Agropolitan Suthomadansih di Kabupaten Karanganyar. Jurusan PKP Fakultas Pertanian UNS. Caraka Tani XXV No. 1 Maret 2010:88-94.

Prapti, Kanthi Pangestuning., Iskandar, R., dan Kasutjianingati. 2015. Strategi Peningkatan Kinerja Supply Chain Buah Nagadi Kecamatan Bangorejo Kabupaten Banyuwangi Berdasarkan Proses Inti SCOR. Jurnal Ilmiah INOVASI Vol. 15, No. 3. Hal. 94-98, September-Desember 2015, ISSN 1411-5549.
Pujawan, I Nyoman. 2005. Supply Chain Management. Surabaya: Penerbit Guna Widya.

Rahayu, Ruwanti Eka dan Kartika, L. 2015. Analisis Kelembagaan dan Strategi Peningkatan Daya Saing Komoditas Kentang di Kabupaten Banjarnegara, Jawa Tengah. JIPI:Vol. 20 (2). Juli 2015: 150-157.

Saptana, dkk. 2006. Analisis Kelembagaan Kemitraan Usaha di Sentra Sentra Produksi Sayuran (Suatu Kajian Atas Kasus Kelembagaan Kemitraan Usaha di Bali, Sumatera Utara, dan Jawa Barat). Pusat Analisis Sosial Ekonomi dan Kebijakan Pertanian: Bogor.

Uphoff, N. 1986. Local Institution Development: An Analytical Sourcebook with Case. Kumarian Press, West Hartford, CN. 